\title{
Seasonal, lunar and tidal control of ichthyoplankton dynamics at the interface between a temperate estuary and adjacent coastal waters (western Portugal)
}

\author{
ANA LÍGIA PRIMO ${ }^{1}$, ULISSES MIRANDA AZEITEIRO ${ }^{1,2}$, SÓNIA COTRIM MARQUES ${ }^{1}$, \\ PEDRO RÉ ${ }^{3}$ and MIGUEL ÂNGELO PARDAL ${ }^{1}$ \\ ${ }^{1}$ CFE - Centre for Functional Ecology, Department of Life Sciences, University of Coimbra, Apartado 3046, \\ 3001-401 Coimbra, Portugal. E-mail address: ana.primo@student.zoo.uc.pt \\ 2 Departamento de Ciências e Tecnologia, Universidade Aberta 752, Rua do Ameal 4200-055 Porto, Portugal. \\ ${ }^{3}$ Centro de Oceanografia/Laboratório Marítimo da Guia. Faculdade de Ciências da Universidade de Lisboa, \\ Av. N. Senhora do Cabo, 939. 2750-374 Cascais. Portugal.
}

SUMMARY: Influence of season, lunar-tide cycle and tide on ichthyoplankton at the interface between Mondego estuary and the adjacent coast and on up-estuary transport was evaluated. Seasonal samples were collected at a fixed station at the mouth of the estuary during diel cycles, at neap and spring tides. Additionally, four sampling stations along the estuary were assessed. Pomatoschistus spp. was the main estuarine taxon, while Sardina pilchardus and Parablennius pilicornis were the most important marine species. Ichthyoplankton entrance and transport along the estuary presented a seasonal pattern with higher densities during summer. Lunar-tide cycle also represented an important influence, structuring communities that reach the estuary and their subsequent distribution. Solea senegalensis and Sardina pilchardus seemed to take advantage of spring tides to enter the estuary. S. pilchardus appear to be using tides to move upstream of the estuary. Ichthyoplankton entrance in the estuary seemed related to species spawning period, while its distribution within the estuary depends on in situ spawning and on the capacity of species to counteract currents and river flow. The present study provides a better understanding of ichthyoplankton dynamics at the interface of two coastal systems, reinforcing knowledge of the lunar-tide cycle influence on ichthyoplankton communities.

Keywords: ichthyoplankton, larval ingress, tidal exchange, seasonality, lunar cycle, larval transport.

RESUMEN: CONTROL ESTACIONAL, LUNAR Y MAREAL DE LA DINÁMICA DEL ICTIOPLANCTON EN LA INTERFAZ ENTRE UN estuario templado y las aguas costeras adyacentes (oeste de Portugal). - Se estudió la influencia de la estación, ciclo lunar y mareas entre el estuario del Mondego y las aguas costeras adyacentes sobre el ictioplancton y el transporte de las larvas hasta el estuario. En cada estación del año, el ictioplancton fue muestreado en una estación fija situada en la desembocadura del estuario, realizandose ciclos diarios en mareas muertas y vivas. Además, fueron muestreadas otras cuatro estaciones en el estuario. Pomatoschistus spp. fue la principal especie estuarina mientras que Sardina pilchardus y Parablennius pilicornis fueron las especies marinas más importantes. La entrada de ictioplancton y transporte a lo largo del estuario presentaron un patrón estacional con mayores abundancias en verano. El ciclo lunar tuvo una importante influencia en la estructuración de las comunidades que llegan al estuario y su posterior distribución. Solea senegalensis y Sardina pilchardus parecen tomar ventaja de las mareas vivas para entrar en el estuario. S. pilchardus parece aprovechar las mareas para moverse hacia la parte alta del estuario. La entrada del ictioplancton en el estuario parece estar relacionada con el periodo de desove mientras que su distribución en el estuario depende del desove in situ así como de la capacidad de las especies de contrarrestar las corrientes y el caudal del río. Este estudio proporciona un mejor entendimiento de la dinámica del ictioplancton en la interfaz de dos sistemas costeros y refuerza el conocimiento de la influencia del ciclo lunar de la marea en las comunidades ictioplanctónicas.

Palabras clave: ictioplancton, ingreso larval, intercambio mareal, estacionalidad, ciclo lunar, transporte larval. 


\section{INTRODUCTION}

Exchange between estuaries and the ocean is a key issue to coastal scientists because many species of fish and invertebrates move between the continental shelf and estuaries during their early life history (Epifanio and Garvine 2001). Transport to an estuarine inlet and subsequent up-estuarine movement are crucial for successful completion of the life cycle of several fish species (Islam et al. 2007). Many fishes using inshore nurseries are targeted by commercially important fisheries. Therefore, evaluating where the pelagic larval stages disperse to and how they manage to successfully recruit back to adult populations is not only critical for understanding the evolution of early life history stages and the dynamics of marine populations, but also for the development and implementation of management and conservation efforts (Forrester and Swearer 2002).

Means of cross-shelf transport and estuarine ingress are not well understood and are often complicated by species-dependent interactions of hydrography (e.g. DiBacco et al. 2001), behaviour (e.g. Queiroga et al. 2007, Jager 1999) and ontogeny (e.g. Hare et al. 2005).

Tidal phase-related factors such as salinity, temperature, chemical substances, current velocity and hydrostatic pressure are reported to be important to plankton distribution (Hsieh et al. 2010). The spring-neap tidal cycle can also have a strong impact on species distribution because the spring tide may hinder vertical stratification (Schultz et al. 2003). This lunar-associated tidal cycle can also play an important role in fish reproduction, acting as cue for synchronization of reproductive events (Oliveira et al. 2009a, Takemura et al. 2010).

Vertical migration according to tidal cycle is a common behaviour linked to transport, retention or dispersion mechanisms. During flood-tide transport larvae settle on, or move close to, the bottom during ebb tide and ascend in the water column during flood tide, resulting in upstream transport (Forward and Tankersley 2001). Additionally, getting out of seaward-moving water layers during ebb facilitates larval retention within an estuary (e.g. Jager, 1999). In ebb-tide transport, larvae settle during flood and ascend during ebb, resulting in seaward transport (Queiroga et al. 2007). Retention mechanisms and selective tidal-stream transport (STT) have been imputed to several species of zooplankton, larval benthic invertebrates (e.g. Queiroga et al. 2007, Jessopp and McAllen 2008, Marques et al. 2009) and larval and juvenile fishes (Schultz et al. 2003, Miller and Shanks 2004, Islam et al. 2007).

Mechanisms of fish larvae ingress and retention in nurseries areas are the focus of several studies across North America (Epifanio and Garvine 2001, Hare et al. 2005, Rooper et al. 2006), Japan (Islam et al. 2007) and Europe (Jager 1999, 2001, Jessopp and McAllen 2008). Little is known concerning the influence of endogenous rhythms associated with the lunar-tide cycle on larval entrance and consequent up-estuary transport and horizontal distribution inside these nurseries areas.

The present study presents the results of a highfrequency sampling, in which diel cycles were sampled seasonally, at neap and spring tide cycle, combined with spatial sampling inside the estuary. The main objectives of this study were: (1) to understand how lunar-associated tidal cycles influence entrance of fish larvae into the estuary; (2) to identify how this influence varies seasonally; and (3) to determine the extent to which this influence affects up-estuary transport and spatial distribution inside the estuary.

\section{MATERIALS AND METHODS}

\section{Study site}

The Mondego River estuary is a mesotidal system located on the western Atlantic coast of Portugal $\left(40^{\circ} 08^{\prime} \mathrm{N}, 8^{\circ} 50^{\prime} \mathrm{W}\right)$ (Fig. 1). The hydrological basin of the Mondego, with an area of $6670 \mathrm{~km}^{2}$, provides an average freshwater flow rate of $79 \mathrm{~m}^{3} \mathrm{~s}^{-1}$ (Dolbeth et al. 2010). Mondego is a well-mixed estuary and consists of two channels divided by the Murraceira Island and converging again near the mouth. Here, the influence of both the river flow and neritic waters is strong and the depth is around 6 to $13 \mathrm{~m}$. The north arm is deeper, with 5 to $10 \mathrm{~m}$ depth at high tide, while the south arm is shallower, with 2 to $4 \mathrm{~m}$ depth at high tide. Tides in this system are semi-diurnal, and at the inlet the tidal range is 0.35 to $3.3 \mathrm{~m}$.

\section{Sample collection}

In order to investigate fish larvae entrance and subsequent up-estuary transport, two different approaches were used. For the high-frequency sampling, ichthyoplankton was sampled at a fixed station located at the mouth of the estuary (M) (mean depth: 8m) (Fig. 1) at 1-hour intervals over a diel cycle. Seasonal sampling took place in June 2005 (summer), September and October 2005 (autumn), December 2005 (winter), and March and April 2006 (spring). In each season two diel cycles were made coinciding with neap and spring tides. Simultaneously, from June 2005 to April 2006, monthly spatial distribution inside the estuary was accessed. Spatial sampling was performed during flood tide by collecting samples at 4 stations distributed throughout both arms of the estuary (S1, S2, N1, and N2) (Fig. 1). Monthly samples were combined into 4 conventional seasons (summer: June05, July05 and August05; autumn: September05, October05 and November05; winter: December05, January06 and February06; spring: March06, April06 and May06) and classified according to the lunar-tide cycle (neap and spring). Neap and spring tides were sampled at least once in each season.

In both surveys, ichthyoplankton was collected using horizontal subsurface tows (bongo net mesh size $335 \mu \mathrm{m}$, mouth diameter, $0.5 \mathrm{~m}$; tow speed 2 knots, 


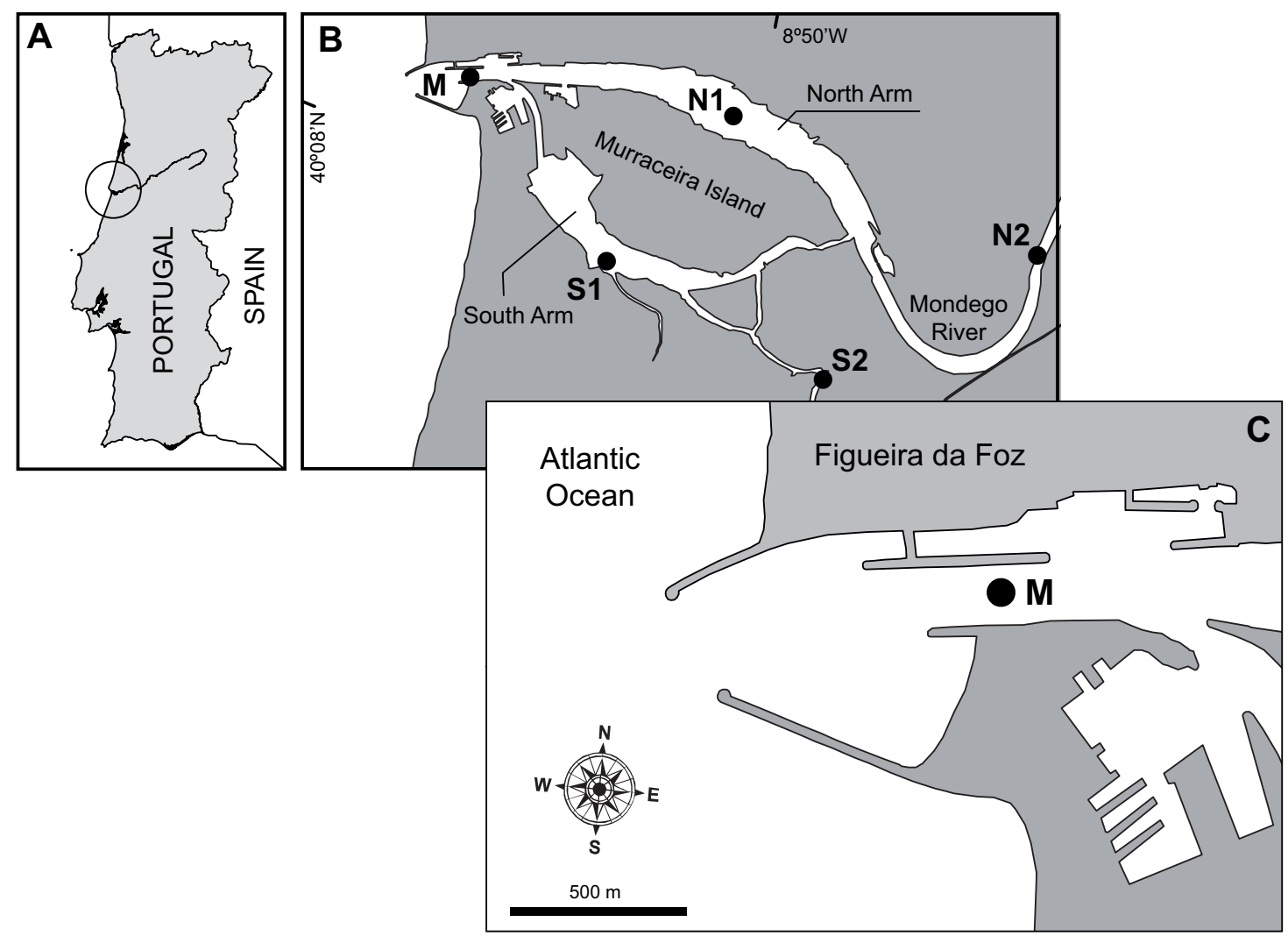

FIG. 1. - Mondego estuary location on the west coast of Portugal (A). Sampling stations sampled inside the estuary (B) in both south (S1, S2) and north arm (N1, N2) and detailed location of sampling site M (high-frequency sampling) (C).

3 min) equipped with a Hydro-Bios flowmeter and preserved in a $4 \%$ borax-buffered formalin seawater solution. Samples were sorted and ichthyoplankton identification to the species level was made whenever possible under a stereoscopic microscope (Primo et al., 2011). Density estimates were standardized (individuals per $100 \mathrm{~m}^{-3}$ ). At each sampling period, salinity, water temperature $\left({ }^{\circ} \mathrm{C}\right)$, dissolved oxygen $\left(\mathrm{mg} \mathrm{l}^{-1}\right)$ and $\mathrm{pH}$ were recorded in situ with appropriate sensors. Subsurface water samples $(1.5 \mathrm{~L})$ were collected for the determination of chlorophyll $a(\mathrm{Chl} a)$ and suspended particulate matter (SPM) (Marques et al. 2006).

\section{Data analysis}

High frequency samples were grouped by season (summer, autumn, winter and spring), lunar-tide cycle (neap and spring tide) and tide cycle (ebb and flood tide). Species were grouped into three main ecological guilds adapted from Elliott et al. (2007): marine stragglers (MS, species that spawn at sea and typically enter estuaries in low numbers occurring frequently in the lower reaches), marine migrants (MM, species that spawn at sea and often enter estuaries in large numbers), and estuarine species (ES, estuarine species capable of completing their entire life cycle within the estuarine environment and those with stages of their life cycle completed outside the estuary).
Statistical analyses were made for each season separately. First, a SIMPER analysis was performed for each ecological guild in order to identify the main species present in each season. Then, variation in environmental factors, guilds and main species densities was tested by a univariate PERMANOVA test. Univariate PERMANOVA tests included a 2-way design (Lunartide cycle/Tidal cycle) and were based on Euclidian distances between samples, after $\ln (\mathrm{x}+1)$ transformation of density data, considering all the factors as fixed and unrestricted permutation of raw data.

Species multivariate analysis was performed using multivariate PERMANOVA. Multivariate tests focused on differences in the assemblage structure between seasons, lunar-tide and tide cycles (3-way design: season/lunar-tide cycle/tidal cycle) and were based on Bray-Curtis similarities between samples, after an $\ln (x+1)$ transformation of density data, considering all the factors as fixed and unrestricted permutation of raw data. For multivariate analysis, samples without larvae and larvae that could not be identified to at least the family level were excluded from the analysis.

Effects of environmental variables on larval fish assemblages were analyzed with canonical correspondence analysis (CCA) (CANOCO version 4.5, Microcomputer Power). Environmental variables included salinity (Sal), water temperature $(\mathrm{T})$ dissolved oxygen 
$\left(\mathrm{O}_{2}\right), \mathrm{pH}, \mathrm{Chl} a$ and SPM. Neap/spring and ebb/flood tides were also included as nominal variables. All species were used and a new category coded as "no fish" was created to prevent CANOCO from eliminating samples containing no fish larvae (Grothues and Cowen 1999). Larval densities were $\ln (x+1)$ transformed and environmental variables were standardized by subtracting the mean and dividing by the standard deviation. Each season was treated separately, applying the forward stepwise selection procedure of explanatory variables in order to identify significant variables $(P<0.05)$. Finally, a total CCA biplot scaling with focus on inter-samples distances was performed using the former identified variables and the nominal variable seasons.

Monthly spatial distribution data were also grouped into seasons and spring-neap tides and species were grouped into the same 3 main ecological guilds (Elliott et al. 2007). Variance in guilds and main species abundance was tested by univariate PERMANOVA tests performed under a 2-way design (Lunar-tide cycle/Sampling station) and based on Euclidian distances between samples, after $\ln (x+1)$ transformation of density data, considering all the factors as fixed and unrestricted permutation of raw data.

SIMPER, univariate and multivariate PERMANOVA tests were applied with PERMANOVA+ and PRIMER software (PRIMER v6 \& PERMANOVA+ v1, PRIMER-E Ltd.) and significant results were investigated using post hoc pairwise comparison tests.

\section{RESULTS}

\section{Hydrological conditions}

Summer spring tide showed significantly lower values of temperature, salinity and Chl $a$. In summer, hydrological conditions showed no differences between tides (Fig. 2, Table 1). At autumn spring tide, temperature was also significantly lower but both salinity and Chl $a$ values were higher than at neap tide. During autumn ebb tides, temperature and $\mathrm{Chl} a$ (mainly during autumn neap tide; PERMANOVA pairwise comparison: $\mathrm{t}($ neap tide $)=2.26, P<0.05)$ ) were lower than during flood, while salinity was higher (Fig.2, Table 1). During winter spring tide temperature and Chl $a$ were, again, lower but salinity continued higher than at neap tide. In this season higher salinity values were recorded during ebb spring tides (PERMANOVA pairwise comparison: $\mathrm{t}$ (spring tide $)=2.75, P<0.05$ ) (Fig. 2, Table 1). Finally, at spring spring tide, temperature was higher than at neap tide but salinity and Chl $a$ were lower. In spring salinity values were generally higher during ebb tide (Fig.2, Table 1). Suspended particulate matter was highly variable during seasonal diel periods, with no significant differences between lunar-tide cycle and tides, exception for winter ebbtide values, which were significantly higher than during floods (Fig. 2, Table 1).
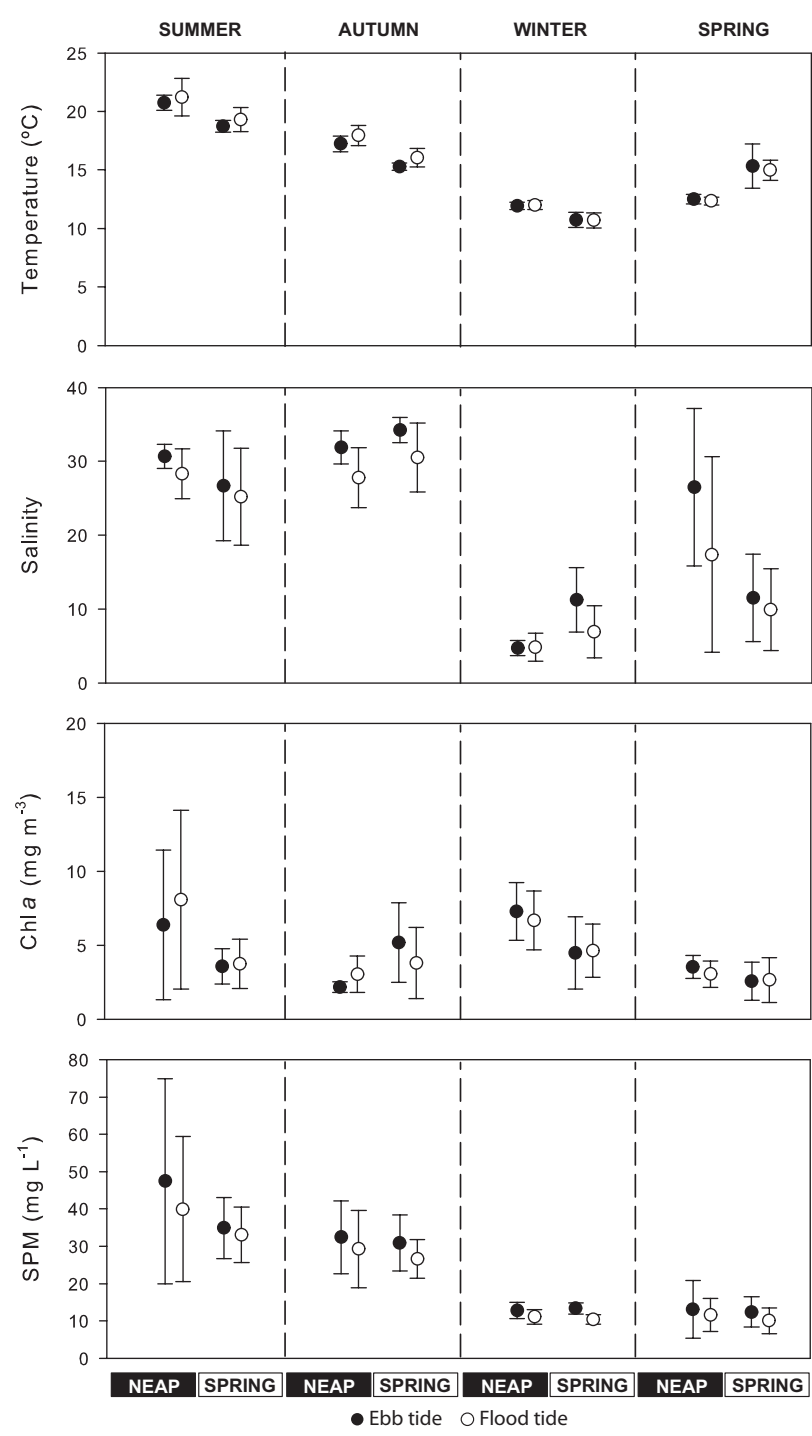

FIG. 2. - Seasonal variation $(\operatorname{mean} \pm \mathrm{SD})$ in temperature $\left({ }^{\circ} \mathrm{C}\right)$, salinity, chlorophyll $a\left(\mathrm{mg} \mathrm{m}^{3}\right)$ and suspended particle matter (SPM, mg

$\left.\mathrm{L}^{-1}\right)$ measured during the high-frequency sampling period.

\section{High-frequency sampling: seasonal and spring- neap tide effects}

A total of 39 different taxa of fish larvae were collected in high-frequency sampling at Mondego estuary. The number of fish larvae was highly variable (ranging from 1 to 1641 larvae $100 \mathrm{~m}^{-3}$ ) and showed a strong seasonal variation, with higher densities in summer, followed by autumn and spring, and finally winter (Fig. 3). Autumn and summer showed no significant differences between neap and spring tides, but both spring and winter showed significantly higher densities during spring tide (Fig. 3, Table 1). Also, there was no significant difference between flood and ebb-tide larvae mean densities, with the exception of the spring spring tide, which showed significantly higher values during flood tide (PERMANOVA pairwise comparison: $\mathrm{t}($ spring tide $)=2.86, P<0.01)$. 
TABLE 1. - Summary results (Pseudo-F values) from 2-way univariate PERMANOVA analysis on environmental and biological variables. SPM, suspended particulate matter; ES, estuarine species; MM, marine migrants; MS, marine stragglers. $* * * P \leq 0.001 ; * * P \leq 0.01 ; * P \leq 0.05$.

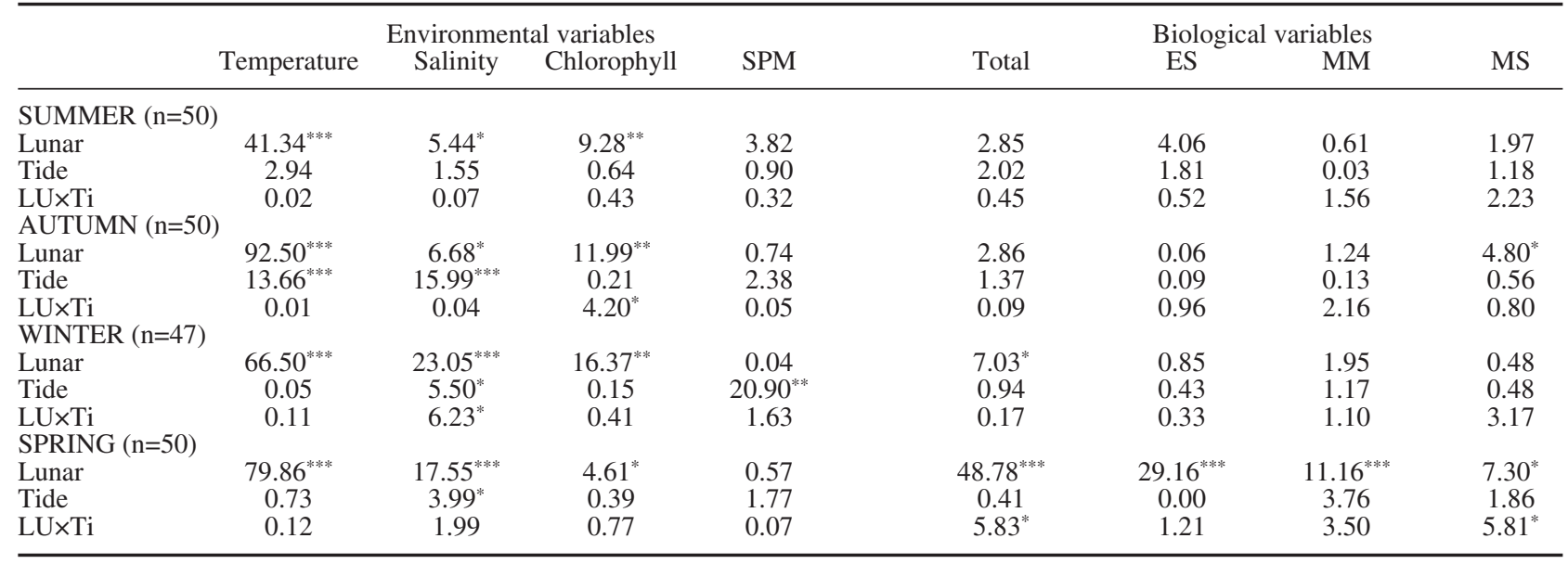
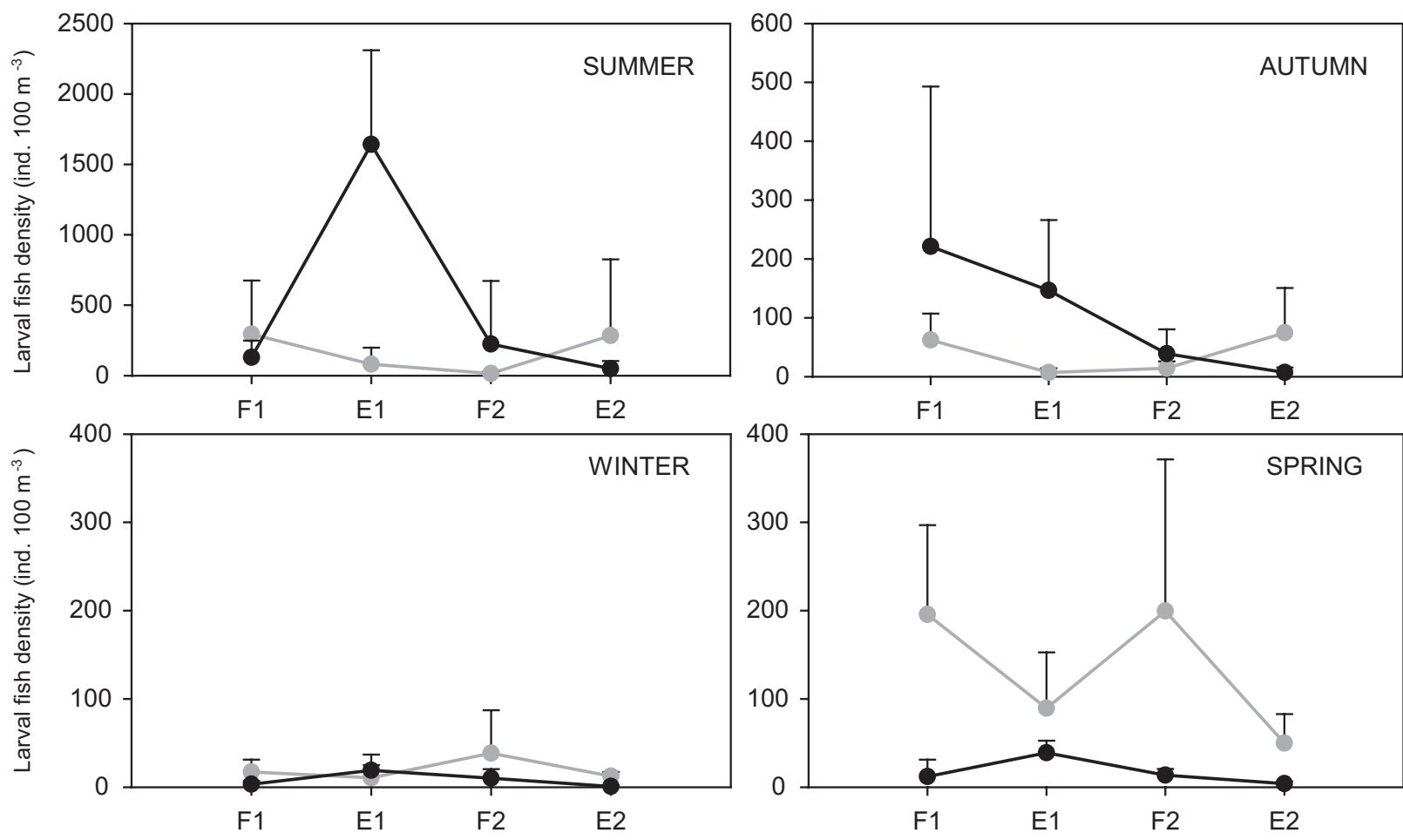

Spring tide

Neap tide

FIG. 3. - Total larval fish densities (mean+SD, ind. $100 \mathrm{~m}^{-3}$ ) in each season and lunar-tide cycle according to tide (F, Flood; E, Ebb).

Estuarine species were the main ecological guild in almost all seasons except winter, when marine migrant species were more abundant (Fig. 4). Marine migrant species increased in winter and spring, while marine stragglers peaked in summer. Estuarine and marine straggler species were higher during summer and autumn neap tides, respectively. In contrast, in spring higher densities were reached during spring tides for the three main ecological guilds (Fig. 4, Table 1). Tide was a significant factor only at spring spring tide (PERMANOVA pairwise comparison: $\mathrm{t}$ (spring tide $)=0.45, P<0.05$ ), when marine stragglers species were significantly more abundant during floods.
SIMPER analysis revealed that Pomatoschistus spp. was the main estuarine species present in all the seasons, the lowest contribution being observed in summer $(70 \%)$ and the highest in winter $(100 \%)$. Sardina pilchardus was the main marine migrant species present in summer $(53 \%)$, winter (100\%) and spring (99\%), while Solea senegalensis showed the highest contribution in autumn (67\%). Finally, Parablennius pilicornis was the main marine straggler species present in larval assemblage, with contributions ranging from $52 \%$ (spring) to $97 \%$ (summer). Note that marine straggler species were absent during winter. 


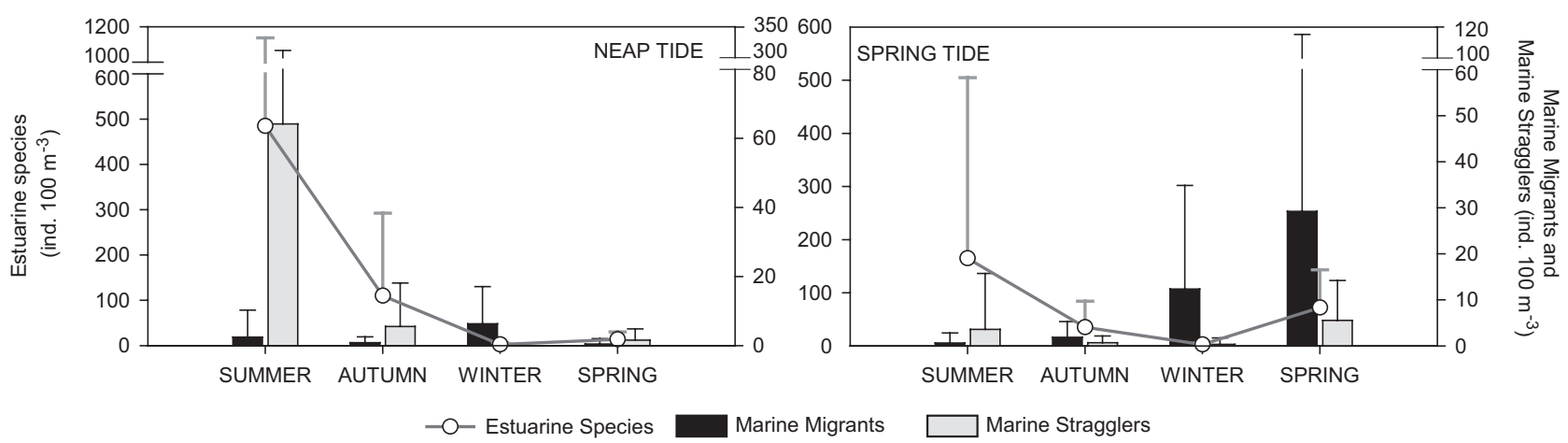

FIG. 4. - Seasonal larval fish densities (mean+SD, ind. $100 \mathrm{~m}^{-3}$ ) of the three main ecological guilds at each lunar-tide cycle. Estuarine species (left axis); Marine Migrant and Marine Stragglers (right axis).

TABLE 2. - Mean density (ind. $100 \mathrm{~m}^{-3}$ ) of the main ichthyoplankton species recorded in Mondego estuary for each season, lunar-tide cycle (neap and spring) and tide cycle (ebb and flood) and results from 2-way univariate PERMANOVA (pseudo-F values) analysis. Standard deviation indicated between brackets. $\mathrm{n}$, sample size. $* * * P \leq 0.001 ; * * P \leq 0.01 ; * P \leq 0.05$.

\begin{tabular}{|c|c|c|c|c|c|c|c|}
\hline & \multicolumn{2}{|c|}{ NEAP } & \multicolumn{2}{|c|}{ SPRING } & \multicolumn{3}{|c|}{ Statistics } \\
\hline & Ebb & Flood & Ebb & Flood & Lunar & Tide & LUXT \\
\hline SUMMER (n) & 13 & 12 & 12 & 13 & & & \\
\hline Pomatoschistus spp. & $574.59(641.53)$ & $142.64(284.78)$ & $154.01(364.41)$ & $130.27(255.70)$ & 2.44 & 1.27 & 0.14 \\
\hline Sardina pilchardus & $1.39(5.00)$ & & & $1.19(2.97)$ & 0.09 & 0.09 & 2.68 \\
\hline Parablennius pilicornis & $112.90(324.47)$ & $2.15(5.25)$ & $4.82(16.70)$ & $2.47(5.97)$ & 1.88 & 1.27 & 2.36 \\
\hline AUTUMN (n) & 11 & 14 & 11 & 14 & & & \\
\hline Pomatoschistus spp. & $59.59(111.34)$ & $144.92(224.62)$ & $34.24(59.55)$ & $33.90(40.33)$ & 2.07 & 4.07 & 0.28 \\
\hline Solea senegalensis & & $0.42(1.53)$ & $1.42(1.98)$ & $1.42(2.98)$ & $5.49^{*}$ & 0.0003 & 0.64 \\
\hline Parablennius pilicornis & $9.79(17.45)$ & $0.61(1.19)$ & $0.26(0.86)$ & $0.41(1.06)$ & $4.85^{*}$ & 2.29 & 3.22 \\
\hline WINTER (n) & 12 & 10 & 12 & 13 & & & \\
\hline Pomatoschistus spp. & $2.35(4.98)$ & $2.15(3.90)$ & $3.26(3.52)$ & $2.14(2.80)$ & 1.23 & 0.22 & 0.57 \\
\hline Sardina pilchardus & $7.39(12.65)$ & $5.01(8.42)$ & $5.08(6.62)$ & $19.07(29.48)$ & 1.95 & 1.17 & 1.10 \\
\hline SPRING (n) & 12 & 13 & 13 & 12 & & & \\
\hline Pomatoschistus spp. & $14.73(16.88)$ & $7.16(12.25)$ & $53.04(44.61)$ & $87.39(90.39)$ & $34.7^{* * * *}$ & 0.44 & 1.86 \\
\hline Sardina pilchardus & $0.33(1.16)$ & & $2.98(6.22)$ & $56.77(119.42)$ & $13.31^{* * *}$ & 3.29 & $4.85^{*}$ \\
\hline Parablennius pilicornis & & & $1.04(1.81)$ & $3.11(4.31)$ & 17.98 & 2.60 & 2.60 \\
\hline
\end{tabular}

Pomatoschistus spp. dominated the ichthyoplankton assemblages in all seasons, except winter. This species density was higher during spring spring tide but no differences were detected between lunar or tide cycle for the remaining seasons (Table 2). The marine migrant S. pilchardus was the main species present in winter assemblages, being evenly present in both spring and neap tide (Table 2). Maximum densities of this species were found during flood in the spring spring tide, reaching a significantly higher density than during the spring-neap flood tide (PERMANOVA pairwise comparison: $\mathrm{t}$ (spring tide) $=4.85, P<0.05)$ (Table 2). $S$. senegalensis reached higher densities in autumn spring tide, with no distinction between tidal cycles (Table 2). Concerning marine stragglers, the presence of $P$. pilicornis increased in summer, with no distinction between lunar or tidal cycle. However, in autumn densities were significantly higher at neap tides (Table 2).

\section{High frequency sampling: assemblage structure and its relationship with environmental variables}

Assemblage structure revealed a clear seasonal pattern, with differences between all the seasons (Pseu-
$\mathrm{doF}=18.96, \mathrm{p}($ perm $) \leq 0.001)$. On the other hand, lunartide cycle influence on species assemblages varied according to season (PseudoF=3.73, $p($ perm $) \leq 0.001)$, being significant in summer $(\mathrm{t}=2.18, \mathrm{p}($ perm $)<0.01)$, autumn $(\mathrm{t}=1.80, \mathrm{p}($ perm $)<0.01)$ and spring $(\mathrm{t}=2.52$, $p($ perm $) \leq 0.001)$, but not in winter. Assemblages were not significantly different between ebb and flood tides.

Forward stepwise analysis showed that in summer significant environmental variables were $\mathrm{Chl} a$, SPM, tide cycle and temperature. During autumn, lunar-tide cycle, salinity, temperature and Chl $a$ were the main variables responsible for structuring assemblages. Chl $a$ and lunar-tide cycle also played an important role in winter, while during spring temperature was the main factor determining the distribution pattern of ichthyoplankton assemblages. The seven environmental variables considered in the final CCA (season, lunar-tide cycle, tide, salinity, temperature, $\mathrm{Chl} a$ and SPM) explained $18 \%$ of the total variation in larval fish assemblages, with first axis accounting for $45 \%$ of species-environment relation. CCA illustrated at least three distinct groups corresponding to spring, winter and autumn/summer (Fig. 5). The distinction between spring and neap tides was also evident. 


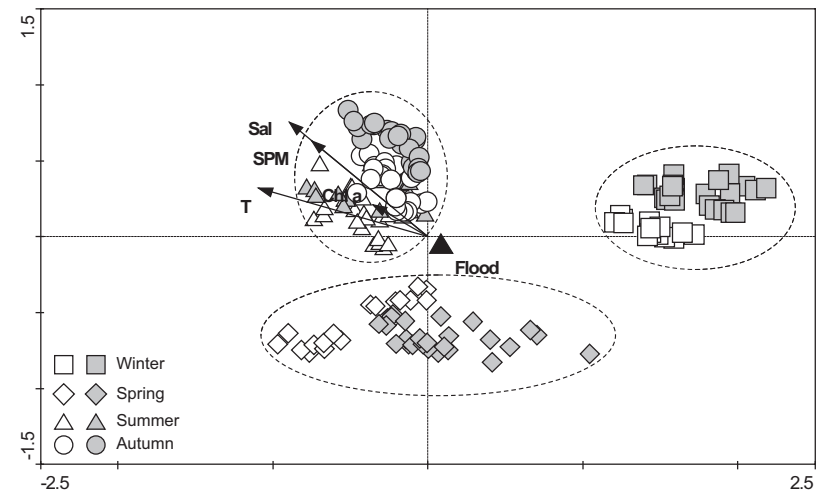

FIG. 5. - Biplot ordination diagram of the larval fish assemblages in Mondego estuary using the first two canonical correspondence axes. Samples were classified according to season (winter, spring, summer and autumn) and lunar-tide cycle (neap and spring). Significant environmental variables are plotted as arrows ( $\mathrm{T}$, temperature; Sal, salinity; SPM, suspended particle matter; Chl $a$, chlorophyll $a$ ). Tide cycle was also included as a nominal variable "Flood". White, neap tide; grey, spring tide.

\section{Seasonal and spring-neap tide effects on spatial distribution}

Estuarine species were present mainly during neap tides except in summer at sampling stations $\mathrm{S} 1$ and N2 and in autumn at stations S1, N1 and N2 (Fig. 6). Marine migrant density was also higher during neap tides, particularly in upstream areas of the estuary. However, downstream sampling stations S1 and N1 showed higher densities at spring tides, mainly in autumn and summer (Fig. 6). Regarding marine stragglers species, higher densities were recorded during neap tides ex-

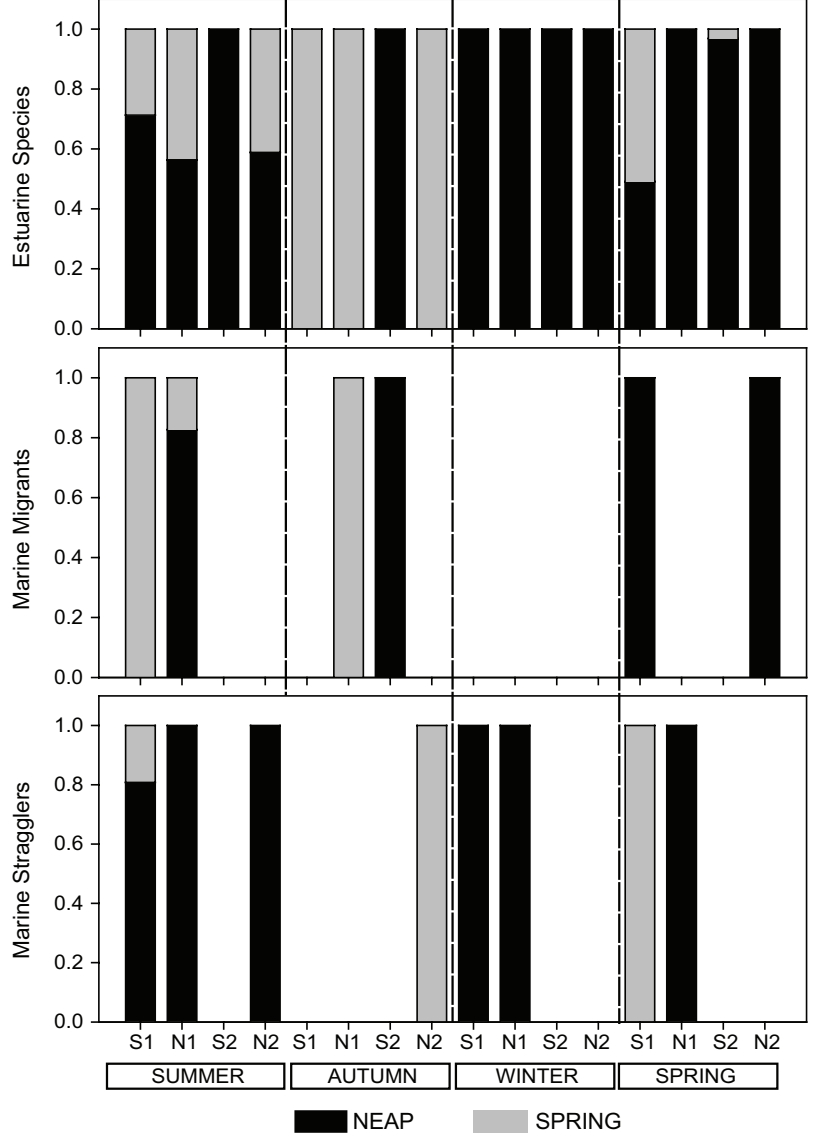

FIG. 6. - Seasonal and spatial relative density of the three main ecological guilds during the 2 lunar-cycle tides.

TABLE 3. - Mean density (ind. $100 \mathrm{~m}^{-3}$ ) of the main ichthyoplankton species in each ecological guild identified in Mondego estuary for each season, lunar-tide cycle (neap and spring) and sampling station and results from 2-way univariate PERMANOVA (pseudo-F values) analysis. Standard deviation indicated between brackets. $\mathrm{n}$, sample size. $* * * P \leq 0.001 ; * * P \leq 0.01 ; * P \leq 0.05$.

\begin{tabular}{|c|c|c|c|c|c|c|c|c|c|c|c|c|c|}
\hline & \multicolumn{5}{|c|}{ NEAP } & \multicolumn{5}{|c|}{ SPRING } & \multicolumn{3}{|c|}{ Statistics } \\
\hline & $\mathrm{M}$ & $\mathrm{S} 1$ & N1 & $\mathrm{S} 2$ & N2 & $\mathrm{M}$ & S1 & N1 & S2 & N2 & Lunar & Station & LUXST \\
\hline SUMMER (n) & 1 & 1 & 1 & 1 & 1 & 2 & 2 & 2 & 2 & 2 & & & \\
\hline Pomatoschistus spp. & & $\begin{array}{c}21.22 \\
(0)\end{array}$ & $\begin{array}{c}5.83 \\
(0)\end{array}$ & $\begin{array}{c}15.00 \\
(0)\end{array}$ & $\begin{array}{c}19.91 \\
(0)\end{array}$ & $\begin{array}{c}7.34 \\
(4.64)\end{array}$ & 8.49 & 6.06 & & $\begin{array}{l}13.93 \\
(8.11)\end{array}$ & 0.97 & 0.86 & 1.31 \\
\hline $\begin{array}{l}\text { Sardina pilchardus } \\
\text { Parablennius pilicornis }\end{array}$ & & $\begin{array}{c}5.95 \\
(0)\end{array}$ & $\begin{array}{l}5.83 \\
(0)\end{array}$ & & $\begin{array}{c}9.95 \\
(0)\end{array}$ & & $\begin{array}{c}1.41 \\
(0)\end{array}$ & & & & $\begin{array}{l}\text { not tested } \\
23.05^{*}\end{array}$ & 6.14 & 4.43 \\
\hline $\begin{array}{l}\text { AUTUMN (n) } \\
\text { Pomatoschistus spp. }\end{array}$ & 1 & 1 & 1 & $\begin{array}{c}1 \\
31.49 \\
(0)\end{array}$ & 1 & $\begin{array}{c}2 \\
0.65 \\
(0)\end{array}$ & $\begin{array}{c}2 \\
2.78 \\
(0.28)\end{array}$ & $\begin{array}{c}2 \\
2.29 \\
(0)\end{array}$ & 2 & $\begin{array}{c}2 \\
5.60 \\
(0.89)\end{array}$ & 0.36 & 2.55 & $8.19^{*}$ \\
\hline Solea senegalensis & & & & & & & & $\begin{array}{c}1.77 \\
(0)\end{array}$ & & & not tested & & \\
\hline Parablennius pilicornis & & & & & & & & & & $\begin{array}{c}3.12 \\
(0)\end{array}$ & not tested & & \\
\hline WINTER (n) & 2 & 2 & 2 & 2 & 2 & 1 & 1 & 1 & 1 & 1 & & & \\
\hline Pomatoschistus spp. & $\begin{array}{c}6.29 \\
(0)\end{array}$ & $\begin{array}{l}26.92 \\
(6.78)\end{array}$ & $\begin{array}{c}7.59 \\
(0)\end{array}$ & $\begin{array}{l}11.97 \\
(3.95)\end{array}$ & $\begin{array}{l}4.76 \\
(0)\end{array}$ & & & & & & $6.18^{*}$ & 0.29 & 0.29 \\
\hline Sardina pilchardus & & & & & & & & & & & not tested & & \\
\hline SPRING (n) & 2 & 2 & 2 & 2 & 2 & 1 & 1 & 1 & 1 & 1 & & & \\
\hline Pomatoschistus spp. & $\begin{array}{c}5.68 \\
(0)\end{array}$ & $\begin{array}{c}16.98 \\
(0)\end{array}$ & $\begin{array}{c}2.80 \\
(0)\end{array}$ & $\begin{array}{l}36.76 \\
(20.10)\end{array}$ & $\begin{array}{c}8.15 \\
(0)\end{array}$ & & $\begin{array}{c}10.54 \\
(0)\end{array}$ & & & & 1.81 & 0.48 & 0.49 \\
\hline $\begin{array}{l}\text { Sardina pilchardus } \\
\text { Parablennius pilicornis }\end{array}$ & & & & & & & $\begin{array}{c}7.02 \\
(0)\end{array}$ & & & & $\begin{array}{l}\text { not tested } \\
\text { not tested }\end{array}$ & & \\
\hline
\end{tabular}


cept at upstream station $\mathrm{N} 2$ during autumn spring tides and in sampling station S1 during spring (Fig. 6).

Pomatoschistus spp. was the most abundant species at all sampling stations and in all seasons, with higher densities in autumn and at spring-neap tides (Table 3 ). Generally, its distribution was uniform across the estuary, with sampling station S2 showing the highest larval densities. Sampling station S1 showed significantly higher densities during autumn spring tides (PERMANOVA pairwise comparison: $\mathrm{t}(\mathrm{S} 1)=0.36$, $P \leq 0.05)$. In autumn spring tides, Solea senegalensis was present at downstream sampling station, whereas Sardina pilchardus was not detected during the spatial assessment (Table 3). Parablennius pilicornis was particularly abundant during summer neap tides and at upstream station N2. In autumn spring tides it also reached upstream sampling station N2 (Table 3).

\section{DISCUSSION}

Seasonal environmental characterization showed that in summer salinity and temperature were higher, mainly during neap tide, which can indicate a stronger marine influence in this lunar cycle. Generally, the same occurred during spring, which showed higher salinity but lower temperature at neap tide. Autumn and winter showed the opposite pattern, with higher salinity and lower temperature during spring tides. Higher river flow during these seasons could reduce the marine influence downstream in the estuary and therefore be noticed mainly during the higher tidal amplitude of spring tides.

High-frequency sampling of ichthyoplankton showed a clear seasonal distribution pattern. Higher densities in summer and lower ones in winter are characteristic temporal patterns usually related to spawning of adult fishes (e.g. Barletta-Bergan et al. 2002, Ramos et al. 2006, Sabatés et al. 2007). A seasonal pattern of fish larvae density has already been reported for the Mondego estuary (Primo et al. 2011).

Winter assemblages differed from the others mainly because of the lower densities of Pomatoschistus spp. and the higher densities of marine migrant species Sardina pilchardus. Winter has already been indicated as a preferred spawning season for S. pilchardus along the western and southern Iberian Peninsula (Stratoudakis et al. 2007) and the northwestern Mediterranean (Olivar et al. 2003, Palomera et al. 2007). This preference seems to be triggered by the decrease in the sea surface temperature (Zarrad et al. 2008).

The marine migrant $S$. pilchardus was also an important contributor in spring, as was Pomatoschistus spp. In fact, Pomatoschistus spp. also represented a large fraction of the assemblage in autumn and summer. Dolbeth et al. (2007) noticed that in the Mondego estuary Pomatoschistus microps has an extended breeding season and several spawning periods, and this is probably the main reason for the importance of Pomatoschistus spp. larvae in assemblage structure throughout the year. Marine stragglers, mainly Parablennius pilicornis, were also a significant fraction of the ichthyoplankton assemblages in summer. This common rocky subtidal fish species has been recorded in Portuguese estuarine environments, mainly in summer in the upper and lower estuary (e.g. Faria et al. 2006). As a marine straggler species, P. pilicornis probably enters the Mondego estuary only during short periods of its larval stage, because its presence in the estuary as a juvenile has not been recorded (Leitão et al. 2007, Martinho et al. 2007).

Higher larval densities of Solea senegalensis in autumn may also be related to the spawning period of the species, which is very variable and consists of two periods, from January to June and in autumn (GarciaLopez et al., 2006). Though it is a marine species, it is common in estuaries and it has been reported to have nursery grounds in several southern Iberian estuaries (e.g. Drake et al. 2002, Cabral et al. 2007).

Lunar-tide cycle influence played an important role in structuring community assemblages, except in winter. However, inside the estuary, winter spatial distribution is affected because during neap tides estuarine guilds showed high densities of Pomatoschistus spp., whereas during spring tides when no fish larvae were caught. This is probably a consequence of higher river flow, which flushed out larvae from the estuary, as has been reported in previous studies (Marques et al. 2006), or of the reduced spawning activity during this season. On the other hand, low river flow periods enable species to reach upstream parts of the estuary, as happened at summer neap tide when larvae of marine stragglers, such as $P$. pilicornis, reached the upper limits of the estuary.

The importance of lunar-tide cycle, not only in fish larval exchange with the adjacent ocean but also in spatial distribution of species within the estuary, may be related to the planktonic nature of larvae that, unable to counteract strong water flow, increase in periods with weak hydrodynamics. Larvae swimming capacity may differ from species to species and according to development stage. Although the present study lacks ontogenetic stage determination, the larvae collected were small (pre-flexion or flexion stage) and were therefore analyzed together.

Marine influence is expected to increase during higher amplitude tides influencing larvae ingress and settlement in the estuary. This is probably the case of the marine species $S$. senegalensis and S. pilchardus, which seemed to take advantage of spring tides to enter the estuary. In small estuaries like Mondego, marine influence is highly dependent on river flow, so higher tide amplitude does not always imply higher marine intrusion, which seemed to be the case of summer spring tides.

Lunar-tide cycle is often related to the spawning period of species. Takemura et al. (2010) observed that during the spawning season of several fishes, synchronous spawning can occur accordingly to a lunar, semi-lunar or tidal cycle. Several studies have demon- 
strated the effect of lunar cycle on the reproduction of S. senegalensis (Oliveira et al. 2009a) and gilt-head sea bream, Sparus aurata (Saavedra and Pousão-Ferreira, 2006). It is thought that lunar or tidal rhythms synchronize fish endocrine organs and induce the beginning of gonad maturation and time of spawning (Oliveira et al. 2009b). Lunar cycle influence seems to be species-specific and related to photoperiod and intensity of moonlight, varying according to species diurnal/ nocturnal behaviour and season (Pankhurst and Porter 2003, Oliveira et al. 2009b, Takemura et al. 2010).

Several studies have shown that fish larvae are able to actively disperse with floods, mainly owing to vertical movements with the tidal cycle (Grioche et al. 2000, Aceves-Medina et al. 2008). The present study considered only subsurface samples and the vertical migration pattern could not be confirmed. Moreover, differences between tidal cycles were only recorded for S. pilchardus, with higher densities during spring spring tide flooding. This may indicate that these species could be using tides to move upstream of the estuary by means of selective tidal-stream transport. Flood-tide transport implies that organisms are abundant in the water column during flood tide and absent or reduced during ebb tide. It is more common in estuarine dependent species, which move up the estuary to nursery or adult habitats (Forward and Tankersley, 2001).

Assemblage structure demonstrated a weak relation with environmental factors, suggesting that other physical variables associated with the spring-neap and ebb-flood tidal cycle could affect fish larval exchange with the ocean. Factors such as wind speed/direction and intensity/direction of currents were not recorded but may play a critical role in these exchanges (Miller and Shanks 2004, Hare et al. 2005, Queiroga et al. 2007). Temperature and salinity showed a strong association with assemblage structure and seasonality. This seasonality may be related to species synchronizing reproduction with the seasonal increase of food (Sims et al. 2004, Sabatés et al. 2007). Chl $a$ and SPM were also important factors in the flux of larvae and both can be associated with turbidity, which is often indicated as an environmental cue for exchanges between estuaries and adjacent coasts (Drake et al. 2007, Strydom and Wooldridge 2005). Tidal flux of larvae is associated with several related factors, including current speed, salinity (as affected by river discharge and magnitude of tidal mixing and exchange), temperature, olfactory cues, turbidity, substrate composition and lunar phase (Strydom and Wooldridge 2005).

The present study reinforces knowledge of lunartide cycle influence on ichthyoplankton entrance into and distribution throughout the estuaries. However, these results could benefit from replicated sampling in each season and lunar-tide cycle and at different depths. Future studies should also include determination of larval ontogenetic stage in order to obtain a more comprehensive understanding of the pattern of entrance and distribution of fish larvae in estuaries.

\section{ACKNOWLEDGEMENTS}

The present work was supported by the Portuguese Foundation for Science and Technology (FCT) through a $\mathrm{PhD}$ grant awarded to A.L. Primo (SFRH/ BD/42351/2007). The authors are indebted to all the colleagues that assisted in the field and lab work.

\section{REFERENCES}

Aceves-Medina G., Saldierna-Martínez R., Hinojosa-Medina A., Jiménez-Rosenberg S.P.A., Hernández-Rivas M.E., MoralesÁvila R. 2008. Vertical structure of larval fish assemblages during diel cycles in summer and winter in the southern part of Bahía de La Paz, México. Est. Coast. Shelf Sci. 76: 889-901.

Barletta-Bergan A., Barletta M., Saint-Paul U. 2002. Structure and Seasonal Dynamics of Larval Fish in the Caeté River Estuary in North Brazil. Est. Coast. Shelf Sci. 54: 193-206.

Cabral H.N., Vasconcelos R.P., Vinagre C., Franca S., Fonseca V., Maia A., Reis-Santos P., Lopes M., Ruano M., Campos J. 2007. Relative importance of estuarine flatfish nurseries along the Portuguese coast. J. Sea Res. 57: 209-217.

DiBacco C., Sutton D., McConnico L. 2001. Vertical migration behaviour and horizontal distribution of brachyuran larvae in a low-inflow estuary: implications for bay-ocean exchange. Mar. Ecol. Prog. Ser. 217: 191-206.

Dolbeth M., Martinho F., Leitão R., Cabral H.N., Pardal M.A. 2007 Strategies of Pomatoschistus minutus and Pomatoschistus microps to cope with environmental instability. Est. Coast. Shelf Sci. 74: 263-273.

Dolbeth M., Martinho F., Freitas V., Costa-Dias S., Campos J., Pardal M.A. 2010. Multi-year comparisons of fish recruitment, growth and production in two drought-affected Iberian estuaries. Mar. Freshw. Res. 61: 1399-1415.

Drake P., Arias A., Baldo F., Cuesta J., Rodriguez A., Silva-Garcia A., Sobrino I., Garcia- Gonzalez D., Fernandez-Delgado C. 2002. Spatial and temporal variation of the nekton and hyperbenthos from a temperate European estuary with regulated freshwater inflow. Estuaries 25: 451-468.

Drake P., Borlán A., González-Ortegón E., Baldó F., Vilas C., Fernández-Delgado C. 2007. Spatio-temporal distribution of early life stages of the European anchovy Engraulis encrasicolus L. within a European temperate estuary with regulated freshwater inflow: effects of environmental variables. J. Fish Biol. 70: 1689-1709.

Elliott M., Whitfield A.K., Potter I.C., Blaber S.J.M., Cyrus D.P., Nordlie F.G., Harrison T.D, 2007. The guild approach to categorizing estuarine fish assemblages: a global review. Fish Fish. 8: 241-268.

Epifanio C.E., Garvine R.W. 2001. Larval Transport on the Atlantic Continental Shelf of North America: a Review. Est. Coast. Shelf Sci. 52: 51-77.

Faria A., Morais P., Chícharo M.A. 2006. Ichthyoplankton dynamics in the Guadiana estuary and adjacent coastal area, SouthEast Portugal. Est. Coast. Shelf Sci. 70: 85-97.

Forrester G.E., Swearer S.E. 2002. Trace elements in otoliths indicate the use of open-coast versus bay nursery habitats by juvenile California halibut. Mar. Ecol. Prog. Ser. 241: 201-213.

Forward Jr. R.B., Tankersley R.A. 2001. Selective tidal-stream transport of marine animals. Oceanogr. Mar. Biol., Annu. Rev. 39: 305-353.

Grioche A., Harlay X., Koubbi P., Lago L.F. 2000. Vertical migrations of fish larvae: Eulerian and Lagrangian observations in the Eastern English Channel. J. Plankton Res. 22: 1813-1828.

Grothues T.M., Cowen R.K. 1999. Larval fish assemblages and water mass history in a major faunal transition zone. Cont. Shelf Res. 19:1171-1198.

Hare J.A., Thorrold S., Walsh H., Reiss C., Valle-Levinson A., Jones C. 2005. Biophysical mechanisms of larval fish ingress into Chesapeake Bay. Mar. Ecol. Prog. Ser. 303: 295-310.

Hsieh H.-L., Fan L.-F., Chen C.-P., Wu J.-T., Liu W.-C., 2010. Effects of semidiurnal tidal circulation on the distribution of holo- and meroplankton in a subtropical estuary. J. Plankton Res. 32: 829-841. 
Islam M.S., Hibino M., Tanaka M. 2007. Tidal and diurnal variations in larval fish abundance in an estuarine inlet in Ariake Bay, Japan: implication for selective tidal stream transport. Ecol. Res. 22:165-171.

Jager Z. 1999. Selective Tidal Stream Transport of Flounder Larvae (Platichthys flesus L .) in the Dollard (Ems Estuary). Est. Coast. Shelf Sci. 49: 347-362.

Jager Z. 2001. Transport and retention of flounder larvae (Platichthys flesus L.) in the Dollard nursery (Ems Estuary). J. Sea Res. 45: 153-171.

Jessopp M.J., McAllen R.J. 2008. Go with the flow: tidal import and export of larvae from semi-enclosed bays. Hydrobiologia 606: 81-92.

Leitão R., Martinho F., Cabral H.N., Neto J.M., Jorge I., Pardal M.A. 2007. The fish assemblage of the Mondego estuary: composition, structure and trends over the past two decades. Hydrobiologia 587: 269-279.

Marques S.C., Azeiteiro U.M., Marques J.C., Neto J.M., Pardal M.A. 2006. Zooplankton and ichthyoplankton communities in a temperate estuary: spatial and temporal patterns. J. Plankton Res. 28: 297-312.

Marques S.C., Azeiteiro U.M., Martinho F., Viegas I., Pardal M.A. 2009. Evaluation of estuarine mesozooplankton dynamics at a fine temporal scale: the role of seasonal, lunar and diel cycles. J. Plankton Res. 31: 1249-1263.

Martinho F., Leitão R., Neto J.M., Cabral H.N., Marques J.C., Pardal M.A. 2007. The use of nursery areas by juvenile fish in a temperate estuary, Portugal. Hydrobiologia, 587: 281-290.

Miller J.A., Shanks A.L. 2004. Ocean-estuary coupling in the Oregon upwelling region: abundance and transport of juvenile fish and of crab megalopae. Mar. Ecol. Prog. Ser. 271: 267-279.

Olivar M.P., Catalán I.A., Emelianov M., Fernández de Puelles M.L. 2003. Early stages of Sardina pilchardus and environmental anomalies in the Northwestern Mediterranean. Est. Coast. Shelf Sci. 56: 609-619.

Oliveira C., Dinis M.T. Soares F., Cabrita E., Pousão-Ferreira P., Sánchez-Vázquez F.J. 2009a. Lunar and daily spawning rhythms of Senegal sole Solea senegalensis. J. Fish Biol. 75: 61-74.

Oliveira C., Vera L.M., López-Olmeda J.F., Guzmán J.M., Mañanós E., Ramos J., Sánchez-Vázquez F.J. 2009b. Monthly day/night changes and seasonal daily rhythms of sexual steroids in Senegal sole (Solea senegalensis) under natural fluctuating or controlled environmental conditions. Comp. Biochem. Physiol. A: Mol. Integr. Physiol. 152:168-175.

Palomera I., Olivar M.P., Salat J., Sabatés A., Coll M., García A., Morales-Nin B. 2007. Small pelagic fish in the NW Mediterranean Sea: An ecological review. Prog. Oceanogr. 74: 377-396.

Pankhurst N.W., Porter M.J.R. 2003. Cold and dark or warm and light: variations on the theme of environmental control of reproduction. Fish Physiol. Biochem. 28: 385-389.

Primo, A.L., Azeiteiro, U.M., Marques, S.C., Pardal, M.A. 2011. Impact of climate variability on ichthyoplankton communities:
An example of a small temperate estuary. Est. Coast. Shelf Sci. 91: 484-491.

Queiroga H., Cruz T., Santos A. dos, Dubert J., González-Gordillo J.I., Paula J., Peliz, A., Santos A.M.P. 2007. Oceanographic and behavioural processes affecting invertebrate larval dispersal and supply in the western Iberia upwelling ecosystem. Prog. Oceanogr. 74: 174-191.

Ramos S., Cowen R.K., Paris C., Ré P., Bordalo A.A. 2006. Environmental forcing and larval fish assemblage dynamics in the Lima River estuary (northwest Portugal). J. Plankton Res. 28: 275-286.

Rooper C.N., Gunderson D.R., Hickey B.M. 2006. An examination of the feasibility of passive transport from coastal spawning grounds to estuarine nursery areas for English sole. Est. Coast. Shelf Sci. 68: 609-618.

Saavedra M., Pousão-Ferreira P. 2006. A preliminary study on the effect of lunar cycles on the spawning behaviour of the gilthead sea bream, Sparus aurata. J. Mar. Biol. Assoc. U. K. 86: 899-901.

Sabatés A., Olivar M.P., Salat J., Palomera I., Alemany F. 2007. Physical and biological processes controlling the distribution of fish larvae in the NW Mediterranean. Prog. Oceanogr. 74: 355-376.

Schultz E.T., Lwiza K.M.M., Fencil M.C., Martin J.M. 2003. Mechanisms promoting upriver transport of larvae of two fish species in the Hudson River estuary. Mar. Ecol. Prog. Ser. 251: 263-277.

Sims D.W., Wearmouth V.J., Genner M.J., Southward A.J., Hawkins S.J., 2004. Low-temperature-driven early spawning migration of a temperate marine fish. J. Anim. Ecol. 73: 333-341.

Stratoudakis Y., Coombs S., Lanzós A.I., Halliday N., Costas G., Caneco B., Franco C., Conway D., Santos M.B., Silva A., Bernal M. 2007. Sardine (Sardina pilchardus) spawning seasonality in European waters of the northeast Atlantic. Mar. Biol. 152: 201-212.

Strydom N.A., Wooldridge T.H. 2005. Diel and tidal variations in larval fish exchange in the mouth region of the Gamtoos Estuary, South Africa Diel and tidal variations in larval fish exchange in the mouth region of the Gamtoos Estuary, South Africa. Afr. J. Aquat. Sci. 30: 131-140.

Takemura A., Rahman M.S., Park Y.J. 2010. External and internal controls of lunar-related reproductive rhythms in fishes. J. Fish Biol. 76: 7-26.

Zarrad R., Missaoui H., Alemany F., Hamza A., Romdhane M.S. García A., Jarboui O., M'Rabet R. 2008. Distribution and abundance of early life stages of Sardina pilchardus in the Gulf of Tunis (Central Mediterranean Sea) in relation to environmental and biological factors. Sci. Mar. 72: 299-309.

Scient. ed.: J.J. Govoni.

Received May 9, 2011. Accepted September 20, 2011.

Published online January 18, 2012. 